\title{
Heinrich Düker: Pioneer in Pharmacopsychology
}

A symposium was organized at Marburg University (FRG) in honor of Heinrich Düker, Professor emeritus of Psychology who was celebrating his 85 th birthday on the 24 th of November 1983.

Among other scientific societies, the 'Arbeitsgemeinschaft für Neuropsychopharmakologie' (AGNP), the German section of CINP, congratulated him. On behalf of the President of AGNP, Prof. B. MüllerOerlinghausen (Berlin), the vice president Prof. W. Janke (Würzburg) stressed Düker's merits in stimulating the development of pharmacopsychology as a behavorial science within psychology and pharmacology.

H. Düker may be considered as the founder of modern German pharmacopsychology prompting many German psychologists and psychiatrists directly or indirectly to undertake research in experimental human pharmacopsychology [for a review, see Debus and Janke, 1981]

H. Düker was a student and assistant of Georg Elias Müller and Narziss Ach at Göttingen University. From 1945 to 1967 he was professor of psychology and director of the Psychological Department of Marburg University.

Düker began his pharmacopsychological work at Schering Laboratories in 1937 after being dismissed from Göttingen University because of his attitude against Hitler. He investigated the behavorial effects of androgens and estrogens in old people by means of a concentration test (the so-called 'Konzentrations-Leistungstest'). Düker [1943, 1957] thus was one of the earliest researchers in experimental endocrinopsychology, which has become a promising field of research.

Later on, he used his test to investigate the effects of stimulants and hypnotics on the central nervous system, with the participation of some of his students (mainly G.A. Lienert, W. Janke, Th. Ehlers, Petra Nettef).

A very important discovery was that decreases in performance induced by sedatives and hypnotics (e.g. alcohol, barbiturates) could not be demonstrated because subjects increased their mental effort to overcome the inhibiting effects of these substances. Düker [1963, 1964] called this phenomenon 'Reaktive Anspannungssteigerung' (reactive increase of effort). This phenomenon turned out to be of basic importance for drug evaluation because many performance tests are not sensitive enough to show the effects of CNS-inhibiting drugs [for a review, see Debus, 1981].

Düker's influence on experimental human behavioral psycho-pharmacology cannot be overestimated. His fight for drug evaluation by means of objective measurement devices and experimental strategies was supported by many of his students and colleagues. And thus, at the present time, a large number of psychological departments (e.g. Aachen: G. Debus; Berlin: Gisela Erdmann; Frankfurt: Ingrid Deusinger; Giessen: Petra Netter; Hamburg: M. von Kerekjar-to; Marburg: Th. Ehlers; Nuremberg: G.A. Lienert, R. Kohnen, W. Oswald: Würzburg: W. Janke, H.P. Krüger; Wuppertal: W. Bouc-seiri), and psychiatric clinics (e.g. Tubingen: H. Heimann; Düssel-dorf: E. Lehman $)$ ), and laboratories of the pharmaceutical industries are doing pharmacopsychological research according to principles which were established by $H$. clinics (e.g. Tubingen: $H$.

Düker 30 or 40 years ago.

Since Düker always regarded experiments with drugs as basic research tools in psychology, a series of papers about this topic will be devoted to him [see Editorial by Janke, 1983]

Wilhelm Janke, Würzbur

References

Debus, G.: Das Konzept der reaktiven Anspannungssteigerung; in Tent, Erkennen, Wollen, Handeln (Hogrefe, Göttingen 1981).

Debus, G.; Janke, W.: Psychopharmacology. Germ. J. Psychol. 5: 149-168(1981)

Düker, H.: Psychopharmakologische Untersuchungen über die Wir-kung von Keimdrüsenhormonen auf die geístige Leistungsfáhig-keit. Arch. exp. Pathol. Pharmakol. 202: 262-313 (1943).

Düker, H.: Leistungsfáhigkeit und Keimdrüsenhormone (Barth, München 1957).

Düker, H.: Über reaktive Anspannungssteigerung. Z. exp. angew. Psychologie 10: 47-72 (1963).

Düker, H.: Über reaktive Anspannungssteigerung als Störfaktor bei der Wirkungsprüfung von Schla

Janke, W.: Pharmacopsychology as a basic and applied science. Neu-ropsychobiology 10: 48 (1983) 